\title{
How do customers evaluate hotel service quality? An empirical study in Tehran hotels
}

\author{
Seyedvahid Najafi ${ }^{\mathrm{a}^{*}}$, Saber Saati ${ }^{\mathrm{b}}$, Mohammad Kazem Bighami ${ }^{\mathrm{a}}$ and Farshid Abdi
}

${ }^{a}$ Department of Industrial Engineering, Islamic Azad University, South Tehran Branch, Tehran, Iran ${ }^{b}$ Department of Mathematics, Islamic Azad University, Tehran-north Branch, Tehran, Iran

\section{CHRON I C L E}

\section{Article history:}

Received May 12, 2013

Received in revised format

12 September 2013

Accepted 7 October 2013

Available online

October 172013

Keywords:

Service quality

Hotel industry

SERVQUAL model

Quality management

Structural equation

\section{A B S T R A C T}

The purpose of this study is to investigate the dimensions of hotel service quality, to assess relative importance of them and to evaluate service quality of Tehran hotels in terms of guests' perspectives. The paper examines the reliability and validity of the designed scale based on SERVQUAL model. A cross-sectional research based on SERVQUAL model conducted on nine hotels in Tehran $(n=1080)$. Several statistical analyses such as EFA, CFA, Linear regression and t-test were applied to analyze the data. Five service quality dimensions were identified and named as "tangibles", "problem solving", "service supply", "empathy" and "security". Even though our findings confirmed five dimensional SERVQUAL constructs, some dimensions have been identified differing from SERVQUAL scale dimensions. Finding showed that the best overall service quality predictor is "tangibles" followed by "service supply", "problem solving", "assurance" and "empathy".

(C) 2013 Growing Science Ltd. All rights reserved.

\section{Introduction}

Iran was ranked $16^{\text {th }}$ in the List of World Heritage Sites for the number of cultural and natural heritage sites, published by UNESCO in 2012 (UNESCO., 2012). Iran is considered as one of the most ancient civilizations of the world and has high potential to develop a rich tourism industry. Tehran, the capital of Islamic Republic of Iran, was the first city in West Asia to host the Asian Games in 1974, and since then, it has continued to host the international sporting events. The possibility of Iran to become the host of some important sporting event such as 2019 Asian Federation Cup (AFC) makes it essential to consider about the suitability, strength and weakness of the current hotels. Current study has conducted by Iran's Cultural Heritage, Tourism and Handicrafts Organization authorities to evaluate the hotels in Tehran. This firm is responsible for making improvement on the quality and standardization of tourism services and facilities as well as issuing licenses and supervising the establishment and administration of hotels and travel agencies.

*Corresponding author.

E-mail address: s.vahid_najafi@yahoo.com(S. Najafi) 
In a specific reforming framework, and to decrease state-owned enterprises and government volume, most of state-owned sectors, except for some backbone industries or those concerning national security will be available for local and foreign investors. For instance, Iranian Privatization Organization has performed so much effort recently to submit the hotel industry to the local and foreign investors (Sohrabi et al., 2012). Therefore, we need to have a clear insight about some important investment measures such as service quality and its importance, which is extracted from view-point of Iranian and foreign tourists. This research was conducted mainly in order to develop our knowledge about important factors affecting hotel service quality. Are there any different dimensions from SERVQUAL model? How customers evaluate service quality?

\section{Literature review}

\subsection{Service Quality Evaluation Related Researches}

Necessary knowledge about product quality is not sufficient to understand service quality as an abstract concept. Hence, there have been tremendous efforts associated with service quality literature about conceptualization of this concept. A common approach among quality specialists is that service quality involves a comparison of customer expectations with his/her perceptions of a service (Grönroos, 1984; Parasuraman et al., 1985). There have been various studies performed to study how customers perceive service quality and how they evaluate this elusive concept (Stauss \& Weinlich, 1997). In some aspects, providing service and production are different and providing service and consuming service occur simultaneously and services are intangible. Therefore, service quality evaluation has become more complex than production quality evaluation (Frochot \& Hughes, 2000). Over the recent decades, there have been various studies developed for service quality evaluation. These methods in which evaluating service quality from the viewpoint of customers is considered, claims perceived service quality as a result of comparison between customer expectation and services they have received. Early research established in this field introduced three dimensions including technical quality, functional quality and image. Functional quality is associated with the quality of service delivery, while technical quality indicates the outcome of the service and image is constructed by technical and functional quality and the effects of some other factors (Grönroos, 1984).

\subsection{The SERVQUAL scale}

Parasuraman et al. (1985) introduced a method for assessing service quality (SERVQUAL) and stated that SERVQUAL could be applied for all service organizations. SERVQUAL was introduced for first time in 1985 and it was revised in many stages later. Their exploratory study finally led to the definition of service quality as discrepancy between perceived quality and customer expectation. They brought up a new phase of quantitative researches to evaluate customer expectation, after identifying service quality dimensions, developed SERVQUAL, and described its structure. This instrument was presented with 97 items first and then after some revisions and adjustments, introduced by 22 items and 5 dimensions as follows (Akbaba, 2006):

Reliability: Execution and fulfillment of services accurately promised, Tangibles: Appearance and tidiness of facilities, assets and personals, Responsiveness: Accountability and willingness of personnel's and providing prompt services, Empathy: Taking individualized notice and intimacy with customers,

Assurance: Setting up trust among customers and competence of employees to inject confidence to customer.

SERVQUAL questionnaire distributes in two stages, first, customer expectations are evaluated by 22 statements and then by similar items customers perceptions of services are evaluated (Zeithaml et al., 1990). Past researches indicate that SERVQUAL as a standard scale for evaluating service quality have attracted academic and practitioners' attentions (Mei et al., 1999). 


\subsection{Service quality in the hotel industry}

According to aforesaid reasons, service quality evaluation is a complex process by itself whereas there is a more complexity in evaluating hotel service quality. Since there is a high demand fluctuation for hotels, this industry is highly sensitive to economic cycles (Chen \& Yeh, 2011). In addition, hotel standards are relatively vague, communications are face to face, and information passes between guests and employees directly (Barrington \& Olsen, 1987). Focusing on these properties, better understanding of hotel service quality can be gained and we can use appropriate indices for evaluating service quality (Asubonteng et al., 1996). In the past, managers were sensitive to superficial perspectives such as location and facilities of hotels, while nowadays the service quality is considered as the key factor in the success of hotels (Wright et al., 1994). In today's competitive world, the recognition of customer's expectation of service quality and services performance function is an essential factor for the success of service businesses. Therefore, identifying strengths and weaknesses of hotels in service providing can help us improve the quality. Surviving in the stiff competition among hotels helps maintain the quality of their productions and services continuously (Ku et al., 2011). Service quality has both direct and indirect effects (through emotional satisfaction) on behavioral intentions in the hotel context (Ladhari, 2009). Most hotels attempting to attract customer satisfaction, significantly have a better position in the hotel efficiency ranking (Assaf \& Magnini, 2012) and it can undoubtedly influence customer behavior. In addition, there is a nonlinear relationship between food and beverage quality and hotels profitability (Chen \& Lin, 2012). Research shows that improving service quality as a strategic instrument could increase customer loyalty and satisfaction (Ekinci et al., 2003), market share and customer positive word of mouth. Satisfaction and commitment of employees improve, which gives a positive image of organization and improves business performance function (Berry et al., 1989). However SERVQUAL has been criticized for several operational and theoretical shortages (Buttle, 1996), it has been implemented widely in service evaluation context. Table 1 demonstrates the results of some studies conducted in Hotel service evaluation context.

\section{Table 1}

Review of some hotel service quality studies

\begin{tabular}{|c|c|c|}
\hline Study & Hotel service quality dimensions & Study Description \\
\hline $\begin{array}{l}\text { (Knutson et al., } \\
1990)\end{array}$ & Tangibles, reliability, responsiveness, assurance and empathy. & $\begin{array}{l}\text { LODGSERV model was introduced and "reliability" was considered as the most } \\
\text { important service dimension. }\end{array}$ \\
\hline $\begin{array}{l}\text { (Oberoi \& Hales, } \\
1990)\end{array}$ & Tangibles and intangibles. & $\begin{array}{l}\text { The study was conducted in a conference hotel in UK and "intangibles" was } \\
\text { introduced as the most important service dimension. }\end{array}$ \\
\hline $\begin{array}{l}\text { (Fick \& Ritchie, } \\
\text { 1991) }\end{array}$ & Tangibles, reliability, responsiveness, assurance and empathy. & $\begin{array}{l}\text { "Reliability" and "assurance" were reported as the most important expectations } \\
\text { concerning service for airline, hotel, restaurant, and ski area services. }\end{array}$ \\
\hline $\begin{array}{l}\text { (Saleh \& Ryan, } \\
\text { 1992) }\end{array}$ & $\begin{array}{l}\text { Conviviality, tangibles, reassurance, avoids sarcasm and } \\
\text { empathy. }\end{array}$ & $\begin{array}{l}\text { The study showed that "conviviality" dimension extracted the most of the } \\
\text { variance. }\end{array}$ \\
\hline $\begin{array}{l}\text { (Webster \& Hung, } \\
\text { 1994) }\end{array}$ & $\begin{array}{l}\text { Tangibles, reliability, communication, responsiveness, security, } \\
\text { understanding and convenience. }\end{array}$ & An easy-to-use questionnaire was Developed. \\
\hline (Akan, 1995) & $\begin{array}{l}\text { Courtesy and competence of the personnel, communication and } \\
\text { transactions, tangibles, knowing and understanding the customer, } \\
\text { accuracy and speed of service and solutions to problems and } \\
\text { accuracy of hotel reservations. }\end{array}$ & $\begin{array}{l}\text { The study was conducted in four and five star hotels and "courtesy and } \\
\text { competence of the personnel" were Introduced as the most important service } \\
\text { dimension. }\end{array}$ \\
\hline $\begin{array}{l}\text { (Ekinci et al., 1998) } \\
\text { (Mei et al., 1999) }\end{array}$ & $\begin{array}{l}\text { Tangibles and intangibles. } \\
\text { Employees, tangibles and reliability. }\end{array}$ & $\begin{array}{l}\text { SERVQUAL instrument was Used in two seaside Turkish resorts. } \\
\text { The study was conducted in five hotels in Australia and a new scale as } \\
\text { HOLESERV was developed. Employees was Introduced as the best predictor of } \\
\text { overall service quality. }\end{array}$ \\
\hline $\begin{array}{l}\text { (Caruana et al., } \\
2000 \text { ) }\end{array}$ & reliability, tangibles, responsiveness, assurance and empathy & $\begin{array}{l}\text { Three column SERVQUAL format was used and three dimensions were } \\
\text { identified. }\end{array}$ \\
\hline (Tsaur et al., 2002) & $\begin{array}{l}\text { Responsiveness, tangibles, meal service, location, reliability, } \\
\text { empathy, reputation, and business service. }\end{array}$ & $\begin{array}{l}\text { The study conducted among international travelers and "responsiveness" and } \\
\text { "tangibles" were ranked as the most significant dimensions of the service } \\
\text { quality. }\end{array}$ \\
\hline (Akbaba, 2006) & $\begin{array}{l}\text { Tangibles, adequacy in service supply, understanding and caring, } \\
\text { assurance and convenience. }\end{array}$ & $\begin{array}{l}\text { The study was conducted in a Turkish international hotel and "tangibles" } \\
\text { dimension was Identified as the most important service quality contributor. }\end{array}$ \\
\hline $\begin{array}{l}\text { (Wilkins et al., } \\
\text { 2007) }\end{array}$ & $\begin{array}{l}\text { Stylish comfort, quality staff, personalization, room quality, } \\
\text { speedy service, added extras, quality food and beverage. }\end{array}$ & $\begin{array}{l}\text { The study conducted in four and five star hotels and They found three main } \\
\text { types of service quality named: physical product, service experience and quality } \\
\text { of food and beverage. }\end{array}$ \\
\hline $\begin{array}{l}\text { (Albacete-Saez et } \\
\text { al., 2007) }\end{array}$ & $\begin{array}{l}\text { Personnel response, complementary offer, tourist relations, basic } \\
\text { demands, tangible elements, security and empathy. }\end{array}$ & $\begin{array}{l}\text { Study sample was selected among in all rural accommodation service users in } \\
\text { Spain. }\end{array}$ \\
\hline (R Ladhari, 2011) & $\begin{array}{l}\text { Tangibility, reliability, responsiveness, confidence and } \\
\text { communication. }\end{array}$ & $\begin{array}{l}\text { Data were collected from } 200 \text { Canadian respondents who had stayed in a hotel } \\
\text { in Canada. The study found that "tangibility" and "communication" are the most } \\
\text { important dimensions. }\end{array}$ \\
\hline (Kuo et al., 2012) & Problem-solving, empathy, Enthusiasm and Friendliness. & Data was collected from guests of international hotels in Taiwan. \\
\hline
\end{tabular}


The implementation of SERVQUAL has showed different results in various cultures and regions. On the other hand, since the level of customers' expectations from service quality are different from one nation to another, it is difficult to validate SERVQUAL (Armstrong et al., 1997). Ariffin and Maghzi (2012) showed that some customer personal factors such as nationality, gender, purpose of stay and private domain of hospitality affect customers' expectation in hotel industry. It seems that to evaluate service quality by comparing customer expectations and customer perceptions in hospitality sector we should take a cautious approach about SERVQUAL scale.

\section{Methodology}

\subsection{Survey instrument}

To evaluate service quality, a questionnaire consists of 29 questions in Likert scale has been designed by considering SERVQUAL dimensions and items. Items were adapted to hotel services and hotel environment. The items used to conceptualize the "tangibles" dimension in the SERVQUAL model are not comprehensive enough (Pantouvakis, 2010), so we add more items to scale it for evaluating "tangibles" dimension. Luoh and Tsaur (2011) performed an investigation among some restaurants in Taiwan. They concluded that customer perception of service quality on tangibles and reliability dimensions with young appearance server was better than server with middle-aged appearance.

In order to conduct Pilot test for examination of instrument reliability, 30 questionnaires were distributed among guests. Questionnaires were filled in presence of researchers and some guests' ambiguities in items were eliminated and necessary revisions were done.

\subsection{Sampling}

The sample study was selected among guests who were stayed in nine hotels, three to five stars. Sampling was conducted between July and October 2012 in Tehran, the capital of Islamic Republic of Iran.1486 samples were divided among 9 hotels guests based on proportionality to their size. Questionnaires were given to Eligible guests (more than 15 years and mentally safe) willing to respond, on the discharge day. Those questionnaires with 50\% unfilled statements and those with one answer for each statement are eliminated, 1080 usable questionnaires were collected finally (response rate $=72 \%$ ). In our survey, $72.5 \%$ of the participants were male and the remaining $27.5 \%$ are female. In addition, $67.8 \%$ of them were married while $26.2 \%$ of them were single. Fig. 1 demonstrates personal characteristics of the participants in terms of age and employment.

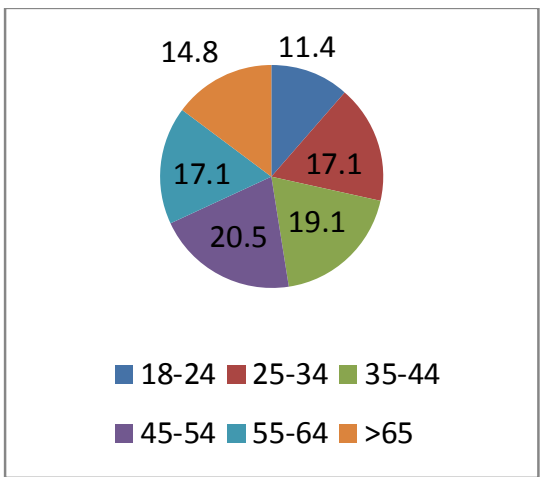

Age

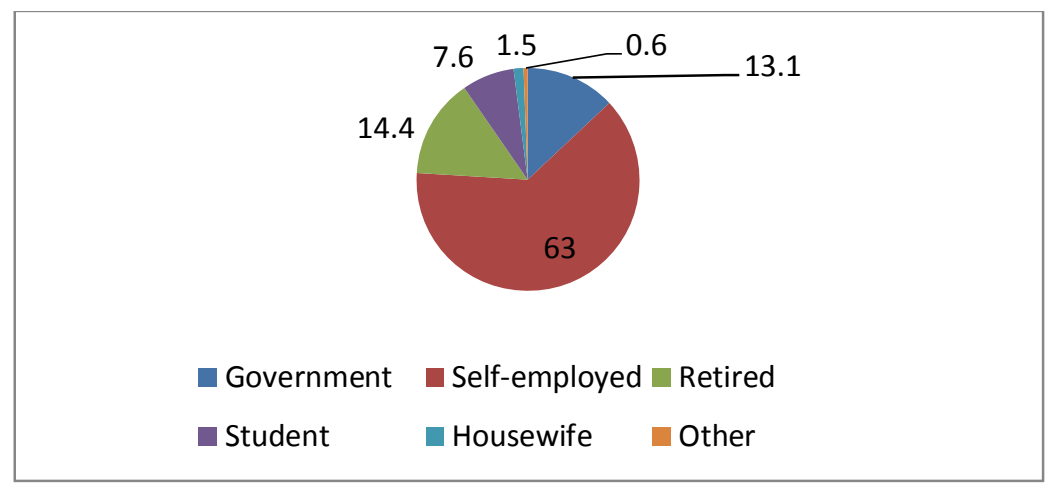

Type of employment

Fig. 1. Personal characteristics of the participants in terms of age and employment

In addition, we have considered participants' educational background as well as purpose of trip and they are shown in Fig. 2 as follows, 


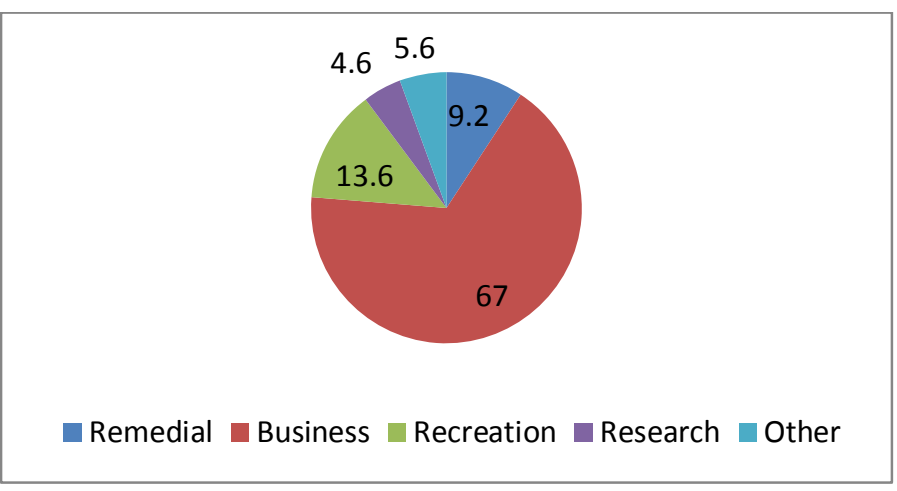

Purpose of trip

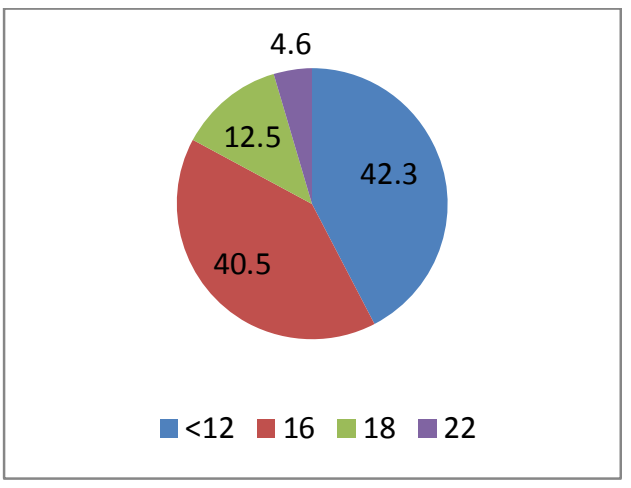

Years of education

Fig. 2. Personal characteristics of the participants in terms of education and purpose of trip Finally, Fig. 3 depicts frequency of trip as well as average income in US dollar.

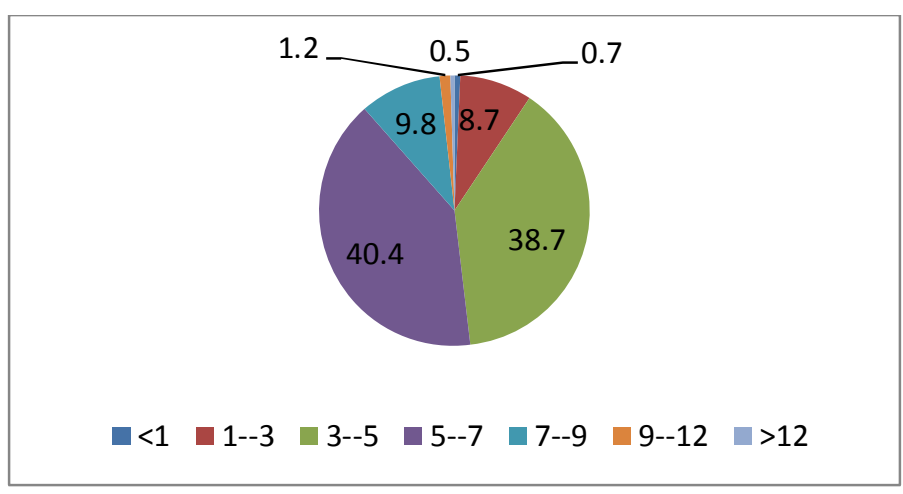

Average income in thousands of dollars

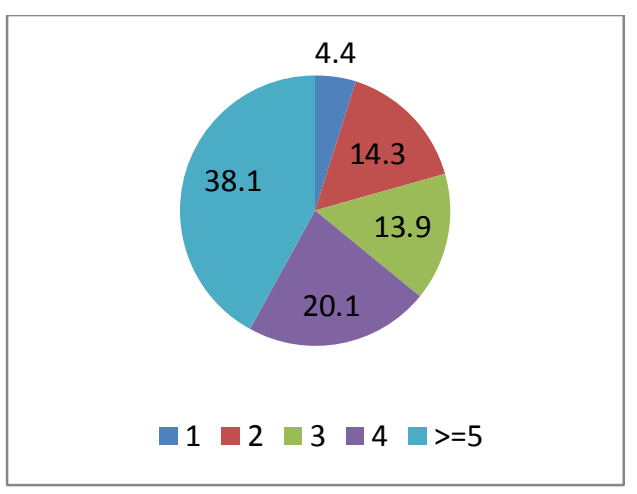

Frequency of trip

Fig. 3. Personal characteristics of the participants in terms of income and \# of trips

\section{The results}

\subsection{Gap analysis}

As mentioned before, SERVQUAL model assesses customer perceptions and expectations around five service quality dimensions and then evaluates service quality by analyzing gap (PM-EM) between them. Negative scores show perceived quality is less than satisfactory, zero gaps mean service quality is satisfactory and Positive gaps means perceived service quality is more than satisfactory. To test the significant difference between perceptions and expectations means, the paired $t$-test was used. Results show that there was a significant different between customer perception and expectation means of all quality items, so guests expectations of hotel service quality had not been met. Table 2 shows perceptions, expectations and gaps means of items and dimensions.

\subsection{Sampling adequacy}

Sampling adequacy was assessed by KMO test. The KMO for 1080 sample was 0.92 that was more than 0.7 (midrange for KMO) and shows samples are adequate for Exploratory Factor analysis (Kaiser, 1960). 
Table 3

Dimensions of hotel service quality, means of guests' expectations, perceptions and quality gaps

\begin{tabular}{|c|c|c|c|c|c|}
\hline Dimensions and & Items & Factor loading & PM & EM & Gap \\
\hline Tangibles & & & 3.89 & 4.83 & -0.95 \\
\hline Q2 & External hotel region (gardens, parking, buildings) is scenery. & 0.78 & 3.96 & 4.86 & -0.9 \\
\hline Q3 & Hotel is outfitted with modern and easy to use equipment. & 0.78 & 3.91 & 4.85 & -0.94 \\
\hline Q5 & Equipment is works well without any breakdown. & 0.75 & 3.88 & 4.83 & -0.95 \\
\hline Q7 & Food and beverage served is completely sanitary. & 0.75 & 3.86 & 4.83 & -0.97 \\
\hline Q1 & Internal decoration (floor, ceilings, furniture, corridors) is stylish. & 0.73 & 3.85 & 4.82 & -0.96 \\
\hline Q8 & Employees' appearance is always neat. & 0.71 & 3.89 & 4.83 & -0.94 \\
\hline Q6 & Public areas are quite clean. & 0.69 & 3.89 & 4.83 & -0.94 \\
\hline Q4 & Facilities and equipment are comfortable, clean and relaxing. & 0.43 & 3.86 & 4.83 & -0.97 \\
\hline Service Supply & & & 3.89 & 4.84 & -0.94 \\
\hline Q17 & All material needed to provide services are enough. & 0.83 & 3.71 & 4.82 & -1.11 \\
\hline Q23 & Hotel services scheduling is flexible and proportionate to guests. & 0.82 & 3.69 & 4.81 & -1.12 \\
\hline Q15 & Hotel tries to minimize all delays. & 0.82 & 3.67 & 4.81 & -1.14 \\
\hline Q16 & The hotel keeps records accurately. & 0.8 & 3.76 & 4.81 & -1.05 \\
\hline Q11 & Employees never linger guests. & 0.75 & 3.74 & 4.87 & -1.13 \\
\hline Q21 & Employees always treat politely especially when quests complain. & 0.6 & 3.7 & 4.8 & -1.09 \\
\hline Empathy & & & 3.71 & 4.82 & -1.11 \\
\hline Q25 & Employees notice to guests before they require. & 0.82 & 3.63 & 4.81 & -1.17 \\
\hline Q27 & Employees give individualized attention to guests. & 0.82 & 3.65 & 4.81 & -1.16 \\
\hline Q28 & The hotel's services are in accordance with guests' needs and desire. & 0.8 & 3.73 & 4.83 & -1.1 \\
\hline Q29 & Employees understand customers' specific needs rapidly. & 0.79 & 3.65 & 4.8 & -1.14 \\
\hline Q26 & Employees try to provide pleasant experience by heart. & 0.79 & 3.67 & 4.82 & -1.15 \\
\hline Q24 & The hotel tries to supports guests in conflicts. & 0.44 & 3.91 & 4.85 & -0.94 \\
\hline problem solving & & & 3.9 & 4.82 & -0.92 \\
\hline Q13 & Employees listen to customers requests with patience. & 0.81 & 3.98 & 4.87 & -0.89 \\
\hline Q14 & Guests can easily express their criticism. & 0.8 & 3.86 & 4.8 & -0.93 \\
\hline Q10 & Employees are willing to solve guests' problems & 0.78 & 3.89 & 4.79 & -0.9 \\
\hline Q18 & All services do in promised time. & 0.72 & 3.87 & 4.84 & -0.96 \\
\hline Q12 & Employees know when and how services provide. & 0.33 & 3.89 & 4.79 & -0.91 \\
\hline Q9 & Employees seem young. & 0.29 & 3.94 & 4.84 & -0.9 \\
\hline Security & & & 3.87 & 4.83 & -0.96 \\
\hline Q22 & Guests have trust and confidence to Employees. & 0.81 & 3.87 & 4.82 & -0.95 \\
\hline Q19 & Hotel completely protects the personal privacy of the guests. & 0.80 & 3.86 & 4.82 & -0.95 \\
\hline Q20 & All security measures is considered by hotel. & 0.80 & 3.89 & 4.85 & -0.96 \\
\hline
\end{tabular}

\subsection{Explanatory Factor Analysis}

29 service quality attributes considering gap scores were evaluated by exploratory factor analysis (EFA).Principle component analysis (PCA) and Varimax rotation method was used to group 29 service quality items into new smaller sets. Eigenvalues of All dimensions was more than 1 and Only items with factor loading equal or more than 0.5 considered significant and used for further analysis (Hair, Anderson, Tatham, \& Black, 1998).Results of EFA showed that five service quality dimensions with 29 items (Table 2) explained 61\% total variance (Table 43). Identified service quality dimensions were named: "tangibles", "problem solving", "service supply", "empathy" and "security".

Table 3

Results of Exploratory Factor Analysis and Reliability test

\begin{tabular}{lccccc}
\hline Dimensions & Eigenvalue & \% of variance & Cumulative variance \% & Cronbach's $\alpha$ & Factor loading ranges \\
\hline Tangibles & 8.786 & 30.296 & 30.296 & 0.88 & $0.69-.0 .78$ \\
Service supply & 2.927 & 10.092 & 40.388 & 0.88 & $0.60-0.83$ \\
Empathy & 2.3 & 7.93 & 48.317 & 0.83 & $0.79-0.82$ \\
Problem solving & 1.969 & 6.788 & 55.105 & 0.78 & $0.72-0.81$ \\
Security & 1.716 & 5.919 & 61.024 & 0.79 & $0.8-.81$ \\
\hline
\end{tabular}




\subsection{Reliability analysis}

Results of reliability test showed that reliability coefficients of five factors are from 0.78 to 0.88 . In addition, reliability coefficient for whole scale is 0.91 , which is well above the minimum desirable level of 0.7 (Sekaran, 2000). Hence, internal consistency exists among items of each factor.

\subsection{Validity of analysis}

\subsubsection{Content validity}

A valid instrument contains all purpose research properties. Instrument statements pretested by some guests and many hotel academician and experts who commented about questionnaire literature, items and order of them. According to specialists advice before final sampling changes has been made.

\subsubsection{Confirmatory Factor Analysis (CFA)}

Confirmatory factor analysis is a special kind of exploratory factor analysis used to verify construct validity and specify consistency degree of construct with researcher understanding of nature of that construct. Model Fitness indices showed the capability of model to use. Verification of construct validity and estimation of model fitness indices carried out using Amos 21. To test fitness of model several indices have been considered, Table 4 shows good overall fit of research model by some important fitness indices.

\section{Table 4}

Results of Exploratory Factor Analysis and Reliability test

$\begin{array}{cccccccc}\text { CFI } & \text { IFI } & \text { NFI } & \text { AGFI } & \text { GFI } & \text { RMSE } & \text { RMR } & \chi^{2} \\ 0.93 & 0.93 & 0.92 & 0.91 & 0.92 & 0.05 & 0.039 & 1123.221\end{array}$

\subsection{Construct Validity}

Construct validity shows whether results obtained using an instrument are fitted to theories underlying tests or not. This evaluation was carried out using convergent and discriminant validity (Sekaran, 2000). Convergent validity shows that all factor loadings are significant and indices loaded on associated factors properly (Kuo et al., 2012). High quantity of Cronbach's $\alpha$ showed proper internal consistency between items and Convergent validity of whole scale. As it seen in Table 3 reliability coefficients of factors was in $0.82-0.93$ range. Cronbach's $\alpha$ for whole scale was 0.77 that is more than 0.7 (Parasuraman, et al., 1991).

Verification of scale construct validity, factor analysis of instrument factors was employed. Factor loading ranges showed in Table 3. Discriminant validity shows different constructs differ from each other and do not have significant overlap. To verify discriminant validity, the correlation between each pair of latent variables should not exceed 0.7.Considering the matrix of standardized correlations, the range of correlation between each pair of latent variables is 0.288 to 0.453 . Hence the significant levels for relations between the latent factors are inferable and discriminant validity was verified for research model.

\subsection{Regression results}

Regression analysis is carried out in order to specify relative importance of 5 service factors in predicting total service quality. Table 6 shows regression analysis results which service factors are independent variables and predict total service quality. As shown in Table 5, five dimensions explained $70 \%$ of total quality variance altogether. 
Table 5

Regression Results, five service quality dimensions predict total service quality ( $n=1080$ )

\begin{tabular}{lccc}
\hline Model & Standardized Coefficients & t-value & Sig \\
\hline (Constant) & & 189.585 & .000 \\
Tangible & .554 & 38.171 & .000 \\
Supply & .470 & 32.351 & .000 \\
Empathy & .223 & 15.366 & .000 \\
Problem & .367 & 25.283 & .000 \\
Security & .247 & 17.025 & .000 \\
\hline
\end{tabular}

Significant level for each dimension was less than 0.05 was equal to zero. Hence, regression model was statistically significant and five service quality dimensions were affected service quality positively. All t-values revealed that the most important service quality predictor was "tangibles", followed by "service supply", "problem solving", "security" and "empathy". This is a fact that "tangibles" is the best predictor of overall service quality is in line with the (Akbaba, 2006; Ladhari, 2011). Pleasing and comfortable environments have positive effects on customers' feeling and service perception, which leads to enhanced behavioral intentions (Lin \& Liang, 2011).

Parasuraman et al. (1988) and Parasuraman et al. (1991) extracted variance from SERVQUAL model dimensions in different services and reported different numbers from $56 \%$ to $70.9 \%$. considering extracted variance by identified factors delineates the necessity of adjusting and adapting SERVQUAL scale to service context (Bouman \& Wiele, 1992; Buttle, 1996; Finn \& Lamb, 1991; Nam \& Lee, 2011; Shoeb, 2010; Tsang et al.; Udo et al., 2011).

Conducted researches in hotel context have reported different dimensions as the most important predictor of service quality. Sorting researches in order of time, (Knutson et al., 1990) "reliability", (Saleh \& Ryan, 1992) "courtesy and competence of hotel personnel”, (Ekinci et al., 1998) "intangibles", (Mei et al., 1999) "employees" and (Akbaba, 2006) and (R Ladhari, 2011) identified "tangibles" as the most effective dimensions which affect hotel service quality perception.

In this study, "tangibles" was identified as the best service quality predictor. This result differs from Parasuraman et al. (1988), which reported "reliability" for this purpose. In addition, this result differs from findings mentioned above in some parts and in literature review about service quality dimensions and the most important dimension in view of customers.

\section{Conclusion}

\subsection{Study objectives and contributions}

This study had three major objectives: First, it explores the dimensions of hotel service quality, second, it assesses the relative importance of hotel service quality dimensions in terms of hotel customers and it evaluates service quality of Tehran hotels.

According to different studies, customers from different cultures and nationalities do not have the same viewpoint to service quality (Armstrong et al., 1997), and extensive exploratory research about hotel service quality in Iran are not enough. Therefore, this research can help domestic and foreign investors and managers of hotel businesses to gain necessary knowledge about service quality. Regarding the first objective and using EFA, five service quality dimensions were identified, which were important for customers of hotels. According to items grouped in each factors, they were named "tangibles", "problem solving", "service supply", "empathy" and "security". "Service supply" and "problem solving" are similar to "reliability" and "responsiveness" in the SERVQUAL model respectively. "security" was also one out of ten original dimensions which was reported by 
Parasuraman et al. (1985). Even though findings confirmed five dimensional SERVQUAL constructs, some dimensions have been identified which are different from SERVQUAL scale dimensions. Considering extensive sampling in this cross-sectional study, it seems that even though SERVQUAL scale is a powerful instrument, it is needed to be adjusted to special service context and environment. Using CFA, convergent and discriminant validity of scale were confirmed.

For achieving second objective, the regression analysis was carried out to assess the relative predictability power of five factors to overall service quality. Finding showed that the best overall service quality predictor is "tangibles" followed in order of importance by "service supply", "problem solving", "assurance" and "empathy".

Regarding the third objective, comparing hotel user's expectations and perceptions shows that perceived hotel service quality was less satisfactory. They have the highest expectations in terms of "tangibles", "security" and "service supply" dimensions. Also they have the highest expectations in terms of "fast response of employees" and "listening to customers' requests with patience". "Empathy", "security" and "tangibles" dimensions respectively had the biggest gap between expectations and perceptions. In terms of the dimensions of service perception, the first was the "problem solving", the second one was "tangibles" and the third one was the "service supply", followed by "security" and "empathy". In terms of the items of service perception, guests had the highest perception from "patience of employees to listen to guests requests".

Along with these important results, designed scale is one of the most important findings.This scale is appropriate for hotels (specially business hotels) and help managers to find out improvement areas, to design service strategies and to make customers satisfied (Asubonteng et al., 1996).

\subsection{Managerial implications}

The extensive effect of service quality on both customers and service providers has been supported by various studies. Better understanding of the service quality in hotels helps hoteliers understand how to increase customer perception of the services. This cross-sectional study was carried out in nine hotels in Tehran can help managers of the hotels to detect the basic dimensions of hotel service quality.

Validity and reliability of five dimensional hotel service quality were conformed. So, managers' efforts should be focused on five dimensions of "tangibles", "problem solving", "service supply", "empathy" and "security".

The "tangibles" dimension explained the highest proportion of total variance, it predicted total service quality better than the other factors and guests had high expectations from "tangibles" dimension. So managers should place special concentration on "tangibles" dimension.

So they should take special attention on stylish, internal and external decoration, cleanness of the rooms and public areas, modern and easy to use equipment, appearance of employees and quality of food and beverage. Providing transportation facilities such as loading and unloading area and car parking area will lead to ease of access to the hotels. It is necessary to provided places for sports and leisure activities such as Gym and swimming pools in the hotels. A big gap observed in the "tangibles" dimension items about hotel equipment. Considering the existing poor communicational tools of Tehran hotels, some advisement for decreasing this gap are: developing wireless communications systems, providing accessibility to Wi fi in the rooms and the other areas of the hotel, using electronic scheduling tools for customizing housekeeping activities, providing interactive room service system, providing business center in rooms outfitted with business software linking to guests online email.

To fulfill the "service supply" dimension, hoteliers should provide the services thoroughly without any shortage and by minimum delay in a consistent scheduling plan for guests. Employees should do 
their tasks immediately and treat guests with respect all the time. They should keep records accurately.

With respect to "empathy" dimension, employees should pay additional attention to guests and give them sincere support so that they believe they are special. Flexible and customized hotel programs help the service users feel individualized attention. Remembering the customer's name and socializing to some degree with them, would make customer's experience positive and their patronage strong (Johnson et al., 2009).

In terms of "problem solving" dimension, the employees should be aware of scheduling and planning of services and try to do tasks in promised time. Listening to guests request carefully and showing enthusiasm to solve their problems leads to customer satisfaction. Listening to customers provides the foundation for understanding and meeting their needs (Mathies \& Burford, 2011).

Getting regular feedback about quality of services would help managers know about guests' insight and fields of improvement to meet guest's needs.

Hotels are supposed to respect to "duty of care", which means they are responsible for providing required standards of security for guests.

Hotels should inject trust to guests by ensuring them about the security of doors, confidentiality of room numbers, placing surveillance cameras in public areas and giving information about hotel construction safety and probable environmental hazards.

\subsection{Limitation and future study}

All the dimensions and items were measured by self-report questionnaires and there may be some concerns on having bias feedback (Sy et al., 2006). By the fact that all the respondents belong to hotels in Iran and the results cannot be generalized to all hotels, the generalizability of the findings is limited potentially. Guests with various programs planned in their journey have no time to complete the questionnaires sincerely. Generally speaking, the limitation of this study mentioned above constrains its generalizability to other hotels. Because of this, a future study has to be repeated in different types of hotels in various countries. Human judgments about service quality as a subjective concept are often vague and it is difficult for guests to express the satisfaction of hotel service quality in a five-point Likert scale. Using fuzzy set theory for dealing with this vagueness and providing more flexible scales is an appropriate method for the future research.

\section{References}

Akan, P. (1995). Dimensions of service quality: a study in Istanbul. Managing Service Quality, 5 (6), $39-43$.

Akbaba, A. (2006). Measuring service quality in the hotel industry: A study in a business hotel in Turkey. International Journal of Hospitality Management, 25(2), 170-192.

Albacete-Saez, C.A, Fuentes-Fuentes, M.M, \& Lorens-Montes, F.J.(2007). Service quality measurement in rural accommodation. Annals of Tourism Research, 34(1), 45-65.

Ariffin, A.A.M, \& Maghzi, A.(2012). A preliminary study on customer expectations of hotel hospitality: Influences of personal and hotel factors. International Journal of Hospitality Management, 31(1), 191-198.

Armstrong, R.W., Mok, C., Go, F.M., \& Chan, A. (1997). The importance of cross-cultural expectations in the measurement of service quality perceptions in the hotel industry. International Journal of Hospitality Management, 16(2), 181-190. 
Assaf, A.G., \& Magnini, V.(2012). Accounting for customer satisfaction in measuring hotel efficiency: Evidence from the US hotel industry. International Journal of Hospitality Management, 31 (3), 642-647.

Asubonteng, P., McCleary, K.J., \& Swan, J.E. (1996). Servqual revisited: a critical review of service quality. Journal of Services Marketing, 10(6), 62-81.

Barrington, M.N., \& Olsen, M.D. (1987). Concept of service in the hospitality industry. International Journal of Hospitality Management, 6 (3), 131-138.

Berry, L.L, Bennet, D.R, \& Brown, C.W.(1989). Service quality: A profit strategy for financial Institutions. Homewood, Illinois: Dow Jones-Irwin.

Caruana, A, Ewing, M.T, \& Ramaseshan, B.(2000). Assessment of the three-column format SERVQUAL: an Assessment of the three-column format SERVQUAL. Journal of Business Research, 49(1), 57-65.

Chen, C.M, \& Lin, Y.C. (2012). Does better service induce higher profitability? Evidence from Taiwanese Hospitality Industry. International Journal of Hospitality Management, 31(4), 13301332.

Chen, C.M, \& Yeh, C.Y.(2011).The causality examination between demand uncertainty and hotel failure: A case study of international tourist hotels in Taiwan. International Journal of Hospitality Management, 31(4), 1045-1049.

Ekinci, Y, Prokopakia, P, \& Cobanoglu, C. (2003). Service quality in Cretan accommodations: marketing strategies for the UK holiday market. International Journal of Hospitality Management, 22(3), 47-66.

Ekinci, Y, Riley, M, \& Fife-Schaw, C. (1998). Which school of thought? The dimensions of resort hotel quality. International Journal of Contemporary Hospitality Management, 10(2), 63-67.

Fick, G.R, \& Ritchie, J.R.(1991).Measuring service quality in the travel and tourism industry. Journal of Travel Research, 30(2), 2-9.

Frochot, I, \& Hughes, H.(2000). Histoqual: the development of a historic houses assessment scale.Tourism Management 21, 157-167.

Grönroos, C. (1984).A service quality model and its marketing implications. European Journal of Marketing, 18(4), 36-44.

Hair, J.F, Anderson, R.E, Tatham, R.L, \& Black, W.C. (1998). Multivariate Data Analysis.NewYork: Prentice-Hall.

Johnson, M.D., Olsen, L.L, \& Andreassen, T.W. (2009).Joy and disappointment in the hotel experience: managing relationship segments.Managing Service Quality, 19(1), 4-30.

Kaiser, H.F. (1960). The application of electronic computer to factor analysis. Educational Psychology Measurements, 20(2), 141-151.

Knutson, B, Stevens, P, Wullaert, C, Patton, M, \& Yokoyama, F.(1990). LODGSERV: a service quality index for the lodging industry. Hospitality Research Journal, 14(2), 227-284.

$\mathrm{Ku}$, C.S., Wu, W.C., \& Lin, A.R.(2011). Strategic alignment leverage between hotels and companies: The buyer-supplier relationship perspective. International Journal of Hospitality Management, 30(1), 735-745

Kuo, C.M, Chen, L.C, \& Lu, C.Y.(2012). Factorial validation of hospitality service attitude.International Journal of Hosptality Management, 31(3), 944-951.

Ladhari, R.(2011).The lodging quality index: an independent assessment of validity and dimensions. International Journal of Contemporary Hospitality Management, 24(4), 628-652.

Ladhari, R (2009).Service quality, emotional satisfaction, and behavioural intentions A study in the hotel industry. Managing Service Quality, 19(3), 308-331.

Lin, J.S.C, \& Liang, H.Y.(2011). The influence of service environments on customer emotion and service outcomes.Managing Service Quality, 21(4), 350-372.

Luoh, H.F, \& Tsaur, S.H. (2011).Customers' perceptions of service quality: do server's age stereotypes matter? International Journal of Hospitality Management, 30(3), 283-289. 
Mathies, C , \& Burford, M (2011).Customer service understanding: gender differences of frontline employees. Managing Service Quality, 21(6), 636-648.

Mei, A.W.O., Dean, A.M., \& White, C.J. (1999). Analyzing service quality in the hospitality industry. Managing Service Quality, 9(2), 136-143.

Oberoi, U, \& Hales, C.(1990). Assessing the quality of conference hotel service product towards an empirical based model. The Service Industries Journal, 10(4), 700-721.

Pantouvakis, A.(2010). The relative importance of service features in explaining customer satisfaction.Managing Service Quality, 20(4), 366-387.

Parasuraman, A, Zeithaml, V.A, \& Berry, L.L.(1985).A conceptual model of service quality and its implications for future research. Journal of Marketing, 49 (4), 41-50.

Parasuraman, A, Zeithaml, V.A, \& Berry, L.L.(1988).SERVQUAL: a multiple-item scale for measuring consumer perceptions of service quality. Journal of Retailing, 64 (1), 12-40.

Parasuraman, A, Zeithaml, V.A, \& Berry, L.L. (1991).Refinement and reassessment of the SERVQUAL scale. Journal of Retailing, 67(4), 420-450.

Saleh, F , \& Ryan, C.(1992). Analyzing service quality in the hospitality industry using the SERVQUAL model. The Service Industries Journal, 11(3), 324-343.

Sekaran, U.(2000). Research Methods for Business: A Skill-building Approach. New York, NY: Wiley.

Sohrabi, B, Vanani, I.R, Tahmasebipur, K , \& Fazli, S.(2012).An exploratory analysis of hotel selection factors: A comprehensive survey of Tehran hotels. International Journal of Hospitality Management, 31 (1), 96-106.

Stauss, B, \& Weinlich, B.(1997).Process-oriented measurement of service quality: applying the sequential incident technique. European Journal of Marketing, 31(1), 33-55.

Sy, T, Tram, S, \& O'hara, L.A.(2006).Relation of employee and manager emotional intelligence to job satisfaction and performance. Journal of Vocational Behavior, 68(3), 461-473.

Tsaur, S, Y.Chiu, \& Huang, C.(2002). Determinants of guest loyalty to international tourist hotels: A Neural network approach. Tourism Management 23(4), 397-405.

Webster, C, \& Hung, L.(1994).Measuring service quality and promoting decentring. The TQM Magazine, 6(5), 50-55.

Wilkins, H, Merrilees, B, \& Herington, G.(2007).Towards an understanding of total service quality in hotels. International Journal of Hospitality Management, 26(4), 840-853.

Wright, P.M, McMahan, G.C, \& McWilliams, A.(1994). Human resources and sustained competitive advantage: a resource-based perspective. International journal of Human Resourse Management, $5(2), 310-326$.

Zeithaml, V.A, Parasuraman, A, \& Berry, L.L. (1990). Delivering Quality Service: Balancing Customer Perceptions and Expectations. New York, NY: The Free Press. 